\title{
Transformation of Shangai at the beginning of the New China Observations from two sino-soviet co-productions
}

La transformación de Shanghái al inicio de la nueva China: observaciones de dos coproducciones sino-soviéticas

\section{Yang $X \mathbf{i}^{1}$}

Shanghai Film Academy of Shanghai University. Shanghai, China 1291727463@qq.com

Citar como: Xi, Y. (2018). Transformation of Shangai at the beginning of the New China. Observations from two sino-soviet co-productions. Desde el Sur, vol. 10, nro. 2, pp. 363376.

\section{ABSTRACT}

Since the Second Opium War, Shanghai was designated as a trading port, and because of its coastal location, the city became an isolated island. Its different from the backwardness of China's semi-colonial and semi-feudal society. Shanghai's "capitalization» is more serious, and social culture is very special. It is a difficult point for a new regime to be supported in the early days of the founding of the People's Republic of China.

This article examines the publicity screenings of the two documentaries in 1950, «The Victory of the Chinese People» (中国人民的胜利) and 《The Liberated China» (解放了的中 国), and analyzes how the two Sino-Soviet documentaries have attracted widespread attention. How did the new regime deploy the film industry's work, talks about the direction of the «film maker» and the «imager» identification mechanism, from the expression of the phenomenon-level viewing to explore Shanghai people's political identity facing the new China.

1 Yang Xi es graduada de la Academia de Cine de Shanghái en la Universidad de Shanghái. Estudia la maestría en Estudios Cinematográficos. Su principal campo de investigación es la historia del cine y la comunicación chinos. En su etapa actual de investigación, se centra en la revivificación a través del análisis histórico detallado del desarrollo de las películas chinas. 


\section{KEYWORDS}

Documentary film, Shanghai citizen, new China, national identity

\section{RESUMEN}

Desde la Segunda Guerra del Opio, Shanghái fue designado como un puerto comercial. Debido a su ubicación costera, la ciudad se convirtió en una isla aislada, separada de la parte continental durante los últimos 100 años de la guerra. Era diferente del resto de la sociedad semicolonial atrasada y semifeudal de China. La situación de «capitalización» de Shanghái es más seria y la cultura social es muy especial. Ello fue un punto difícil de conquistar por el nuevo régimen durante los primeros días de la fundación de la República Popular de China.

Este artículo examina las proyecciones publicitarias de dos documentales de 1950, La victoria del pueblo chino (中国人民的胜利) y La China liberada (解放了的中国), y analiza cómo estos trabajos sino-soviéticos merecieron una gran atención. Asimismo, se propone responder cómo el nuevo régimen desplegó el trabajo de la industria cinematográfica, y pensó en la dirección del «cineasta» y el mecanismo de identificación «imaginador», desde el fenómeno de la visualización causada por estos dos documentales, para explorar la identidad política del pueblo de Shanghái con la de la nueva China.

\section{PALABRAS CLAVE}

Película documental, ciudadano de Shanghái, nueva China, identidad nacional

\section{That times background}

In 1949, the new China ushered in full liberation. While people em braced victory, the new regime also began to take over the government and gradually establish a socialist system. For the vast majority of inland cities with a profound local Chinese tradition, it was only a matter of time to adapt to the red regime that has grown up from the «Rural encircled City» route. It is undoubtedly difficult to establish a socialist revolutionary system on the Shanghai Bund, which exuded a sense of «Shanghai-style culture». Under such background, the adjustment of Shanghai's «foreign appetite» to the people of Shanghai has become a difficult point in the 
construction of socialist culture. The process of citizen's ideas and identity transformation is worth studying.

In January 1949, 16 people from film and cultural circle such as Ouyang Yu qian, Cai Chu sheng, Shi Dong shan and Yang Han sheng proposed the «Movie Policy Offer» (电影政策献议). The first sentence is «Film is a kind of cultural and educational tool with advantages. It has great expressiveness and wide spreading power. Because of its superiority, it can serve the people more effectively, the socialist Soviet Union, has long regarded the film as one of the important undertakings of the state-owned enterprise» ${ }^{2}$. Under the guidance of the full scale soviet-style and «one-sided» policies at that time, Soviet films have brought significant influence to Chinese films. Together with the Soviet «Party Film» (党论电影) published in China, Lenin's important discussion on documentary films became the theoretical guidance of documentary workers. The concept of documentary film as «a visualized political theory» was determined.

«The Victory of the Chinese People» and "The Liberated China» have been the first batch of Chinese and Soviet co-productions since the founding of the People's Republic of China. They practiced the creative tenet of "Arts should serve the workers, peasants and soldiers», and were released simultaneously in 15 cities of China after the completion of excellent production standards. On September 30, 1950, «The Victory of the Chinese People» was released at major theaters in Shanghai. Three months later, on December 30, «The Liberated China» was also grandly released during the New Year. Reflecting the emergence of these two documentaries, it is like a clear stream that has injected a new patriotic enthusiasm into the Shanghai cinema line, setting off a large-scale viewing craze.

\section{The historical landscape inspires national identity. Plentiful image texts of "old and new Shanghai» abound}

\section{Recall the sufferings and criticize the old society}

The main reason for the «victory of the Chinese people» and «The Liberated China» to attract the attention and resonance of the majority of Shanghai residents comes from the video content of the documentary. The description of the Shanghai area has occupied a lot of space in these two documentaries. The city has witnessed too many important historical events in the history of modern Chinese struggle against salvation (sic). The people on this land have experienced many hardships. Regardless of how «internationalized» Shanghai has been as a metropolis on a Chinese

2 Ouyang yu qian et al, Film policy proposal (Wu di, 2006). 
map, the aura of the city does not bring much benefit to the lives of the general public. The majority of the workers in the masses have been experiencing oppression for a long time. The squeezing of imperialism, feudalism, and bureaucratic capitalism is miserable.

However, the establishment of the new China has completely changed all of this, and the proletariat, which constitutes the vast majority of the urban population stands up. «The Liberated China» has a historical review of several landmarks in Shanghai. The film says: «The Shanghai Bund, which houses the largest foreign banks, various foreign banks and foreign companies»; "In the concession, the invaders built many skyscrapers, many comfortable mansions and luxury shops»; "Shanghai Huangpu River has many foreign merchant ships imported every day, British and American capitalists dumped foreign freight to China». Following the passionate commentary, the shots reveal the flag of the imperialist bandits, the grid and pillbox on the walls of the consulate, as well as many skyscrapers and luxury mansions, which are a sign of insults in the hearts of the audience. They used to be indignant and angry, but the film helped them vent their anger.

The contrast between local residents and foreign outlanders further deepens the hatred of the people for imperialism. There is such a narrative in «The Victory of the Chinese People»: "Shanghai, this is a sinful city of exploitation. On the ports of hundreds ships, there is no modernized unloading equipment because the labor of people here is worth nothing». «Rickshaw drivers, they have no home, they run on the streets all day, summer and winter, sleep at night. Beside their own wheels, even these wheels are not theirs [...] The Chinese people have only one right left - to sell their labor for a few cents. The Chinese city, the China's land does not belong to Chinese people».

The shots is not only to show the sadness of the past, but also to reveal the evil backstage manipulator -it is the imperialist powers and the reactionary Nationalist Party oppressing the people, accusing and criticizing the old forces, in order to thoroughly purge the masses of their knowledge of the evil acts of the enemy. The feeling followed by the hatred of the former is the gratitude and love of the savior. In the new China, most people in Shanghai have completely changed their places. The film has carried out class education through the combination of sound and picture. This type of documentary was promoted as easy-to-understand, and the workers and peasants, whose knowledge level is generally low, have clearly recognized the change of political system's great significance, and naturally extended to the identification and conversion with the new government. 


\section{The Communist Revolution established a new socialist faith}

In addition to showing the past bitter history and difficult struggles, the documentary spurs the public to escape the old system, and also portrays the trajectory of the growth of the red regime, setting a new look for trustworthy regimes. Shanghai carries a humiliating past and also breds bright hopes. It is the Chinese Communist Party that ended all this tragic history. On July 1, 1921, the Chinese Communist Party held its first national congress in Shanghai, all Shanghai residents are very proud of it. The narrative of «The Liberated China» has turned to high from this moment: «Shanghai Nanjing Road, on this road, on May 30, 1925, workers who held patriotic parade suffered a killing by British patrols. Today, at the crossroads where the martyrs flowed through their blood, young men and women celebrated their liberation in a carnival. The Chinese people have forever consolidated their nationalism and firmly embarked on the road of democracy and freedom».

In addition to the turnaround of political and social rights, the changes that ordinary people can realize come from the tremendous changes in the working environment: «Female workers in the Shanghai mill with revolutionary traditions adopted new methods to increase production firstly. The posters praised the advanced, criticizing the laggards». «When we are engaged in peaceful construction, the traitor Chiang Kai-Shek bombarded the peaceful residents of Shanghai with American planes. The Shanghai Shipyard was bombed every day, but the factory did not stop working. Rao Shushi and Chen $\mathrm{Yi}$, leaders of the communist party and government in eastern China, visited the shipyards to encourage workers repair damaged boats.» The workers with such experience are precissely the target of this documentary. They have never had a strong sense of substitution in the movie. In the past, there were few scenes of ordinary workers on the screen. The class that has never been valued has become the main force of social construction now. This kind of pride has further evolved into a sense of historical participation. Now the Communist Party of China has established political power and the working people have turned over. Becoming the creator of social value, the status of the class has been greatly improved, what could be more rewarding than having your job recognized?

«The Victory of the Chinese People» specifically shows the liberation of Shanghai. «The workers in Shanghai have risen to protect the factory under the leadership of the Communist Party. These properties will be long to the people tomorrow. They are determined not to allow the Nationalist Party to destroy Shanghai before it flees. The Third Field Army rushed into the big city with a population of 6 million from all directions and 
immediately made progress to the city center. These complicated streets, like spider webs, are not easy to recognize, but the postmen volunteered to help guide the way, they put every street and every house to tell the soldiers, «The workers played a real role in the battle». Thousands of workers participated in the great historical transformation together, witnessing the Chinese map being covered with dense red flags, the people are firmly committed to create a new world of their own. The happiness of living in new China arises spontaneously, and then escalated into a conscious recognition of the will of the country, and the legitimacy of the Communist Party's governance was established.

The films' performance on the history of the war of salvation evokes the traumatic memory of Shanghai residents and the recognition in «one mother compatriot» of the New China. Although these people have been westernized for a long time, the umbilical cord of Shanghai and China sharing the same fate has never broken. «History is the most important educational tool for the formation of national identity» (Duara, 2003, p. 11), through the comparative narration of the film, the audience feels the greatness of the national image, fully approves and converts to the legitimacy of the new China.

\section{The unprecedented national viewing. Carnival-like publicity tactics}

These two documentaries were very popular in Shanghai cinemas at the time, the box office and attendance have repeatedly hit new highs. They were inseparable from the government departments, newspaper media, and commercial organizations. When «The Victory of the Chinese People» was released, Shanghai's five mainstream cinemas - International, Great Shanghai, Hu guang, Meiqi, and Da guang ming Theater-were «Gloriously Presented», which was shown until November 15, 1950. «According to statistics, in the month of September, the number of Shanghai movie viewers increased to 1.91 million, which is close to the highest record of the previous Shanghai cinema sales» (Jin Yan, October 21, 1950). When «The Liberated China» was released on the eve of New Year's Day in 1951, The «Special Column» proudly reported: «In 15 cities across the country, 19 shows have been booked in six days, with more than 160,000 audience» (Jin Yan, December 30, 1950).

For the purpose to make the documentary film truly serve the people, the government department sat a very low price for the movie ticket make a $40 \%$ discount on the fare of $3,000,4,000$ and 5,000 RMB; $20 \%$ off for groups of 20 or more; $20 \%$ off for groups of 10 or more. Moreover, the audience received a souvenir medal for the movie. The Propaganda 
Committee of the Shanghai People's Government has adopted a variety of methods for in-depth publicity: leaflets, posters, radio broadcasts, symposiums, etc., which mobilized all kind of social forces to expand the film's affection. Before the film's release, the newspaper will preview for dozens of days in advance. When «The Victory of the Chinese People»was exhibited, «Wen Hui News», «Liberation Daily» and «Ta kung pao»were notified for 26 days, 24 days and 14 days respectively.

When «The Liberated China» was released, all three newspapers published publicity seven days in advance, and specialized of the "Special Column", gave a full-page layout of the film review. Political leaders, literary and art celebrities, and film critics published articles zealously: Such as Shen Yan bing, Yuan Mu zhi, Xia Yan, Yu Ling, Xu Xiao bing, Tang Mo, Hu Di, Yuan Xue fen [...] all contributed to the recommendation, Л.В.Варламов and С.А.Герасимов's speeches were also published with translations in the newspaper.

In addition, reporters of the newspaper continued to follow up. As the release date was closer, trailers become more detailed and the size of the images becomes larger and larger. The advertising copy of the film is also superb, it praised «The Victory of the Chinese People» as follows: «By means of the cooperation of excellent film workers from China and Soviet: Within 10 months, traveled all over the whole country, the mountains and ridges, the Yangtze River, complete the glorious mission with a highly internationalism and patriotism. «Look at the crescive history of our great and free country; the full picture of our vast and fertile motherland; our heroic and invincible people, the great achievements of the People's Liberation Army; our strong alignment to defend the forces of peace and democracy!» (Jin Yan, September 29, 1950). Reading between the lines, the movie advertising discourses are filled with strong patriotism.

The advertising for «The Liberated China» has such a description: «The film that everyone must watch in the War to Resist US Aggression and Aid Korea, enhance political consciousness, stimulate patriotic enthusiasm», «This film will help the audience to correctly understand the lovely motherland». We can see the cultural strategy expression of the above movie advertising discourse and the strengthening of national consciousness. These words arouse the national pride of Shanghai audience with aggression trauma, revolutionary history and combat achievements. People's recognition of the new China comes to life. Convey a clear sense of social responsibility and political orientation.

For the sake of attracting more people to come and watch, all walks of life have participated in the film's promotion. On one hand, it expresses support attitude towards the new government policy; on the other hand, 

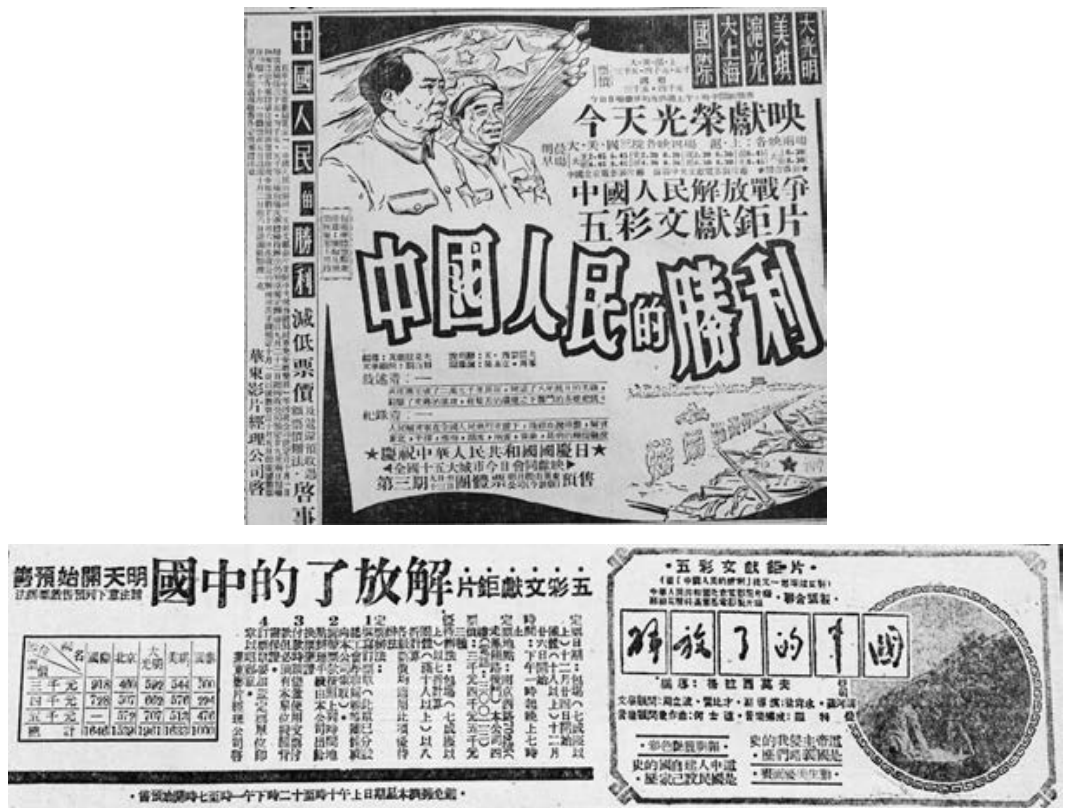

Advertisements of «The Victory of the Chinese People» and «The Liberated China».

it can expand the visibility of its own commercial brands. There was a flurry of advertising for various incentives, and the booking market became boisterous. «Popular movies» published an important revelation in «Ta Kung Pao»: the eighth issue is the special volume of «The Victory of the Chinese People», which reduce for 1000 RMB per copy. After 29 days of release, the major cinemas simply gave away: "A special volume of "Popular movies" is included with the ticket. Each cinema is limited to send 5,000 copies». Other commercial tycoons also come to recommend, «Hong xi» Cigarettes were given an advertisement for sending the tickets of the film:

Purchase 4 packets of «Hong xi» cigarette at once, you will gain a film ticket

Bring forth 20 empty packets box of «Hong xi» cigarette, you will gain a film ticket

This event are limited before October 11

There set three issuing offices (Gui zhou Road, Yan'an Middle Road, Tian mu Road)

The Nanjing Theatre and the Family Industrial Cooperatives jointly held a prize-winning event:

Every lottery is given one toothpaste, and the first prize is worth 5 million yuan. The prize is easy to win; 
The Golden Theatre joined forces with the Da lu Pharmacy:

Continue to give away the skin cream each screening (including the morning), and with the ticket stub, you can draw on the spot (Jin Yan, October 3, 1950).

The promotion of major newspapers, the coordination of industry organizations, the advertising promotion strategy, and the sincere love of the film for the performance of new Chinese-themed films have ushered in a fierce movie watching situation of the New China Documentary Film. Before the release of «The Victory of the Chinese People», many workers, peasants, and students had never seen a movie, but this one caused the theater to lower the fare and give these audiences opportunities to step into the theater. Under the concerted efforts of all people, the number of viewers and box office receipts have repeatedly broken records in the Shanghai film industry.

When «The Victory of the Chinese People» was released, in 21 days, the operating income of five cinemas - Da guang ming, Meiqi, Hu guang, Grand Shanghai and International, was bigger than the gross income of their previous month. «The number of spectators in April this year was only 1.56 million. In September, it increased to 1.91 million. It is on the verge of surpassing the previous record for cinema attendance» (Jin Yan, November 3,1950 ). Such an achievement can be said to be unprecedented. The «foreign appetite» of Shanghai residents did not appear to be difficult to serve. The feedback was excellent, and the box office was sold out repeatedly. Shanghai citizens' attitude towards the new Chinese regime can already be appreciated in the acceptance of these two documentaries. The favorable impression of the film and the trust in the new regime have grown simultaneously, and the approval of the new regime led by the Communist Party of China is deeply rooted.

\section{«Ban Capitalistic films» and "Praise domestic films». Rectify the new rules of the film industry}

The edification brought by «The Victory of the Chinese People» and «The Liberated China» just in line with the implementation of the new policy of socialist film reconstruction, that is, the ban on US and British films. Before the founding of the People's Republic of China, American and British films (especially American films) were rampant in Shanghai and most parts of the country. «According to the statistics in 1949 Shanghai, 130 films were screened from the United States and Britain's, accounting for $63.7 \%$ of all the films shown» (Yang yuan ying, 2006). In July 1950, the Administrative Council promulgated the «Interim Measures for the Cleaning of Old Movies» and the «Interim Measures for the Importation of Foreign Films», gradually 
began to remove the negative United States and Britain films from the Chinese market. In Shanghai, «more than 40 cinemas have agreed on labor and capital, accepting the justice requirements of the masses, and patriotism is in no particular order. Since November 14, 1950, the city's cinemas have stopped filming the negative films» (Wu yi gong, 1999, p. 598).

At the same time, the war of the Chinese People's Volunteers to go to the DPRK to defend the country is also continuing. All sectors of society have spontaneously opposed American movies. They have slandered the US film and tormented these «reaction films» aggression, calling for the «Manufacturing of germs - Hollywood movies» to be driven out of the country, using movies as weapons to resist US aggression. In the spur of patriots and progressive publics, American movies were excluded from the Chinese mainland market, while on the other side, the major theaters vigorously promoted and supported the two Chinese-Soviet co-production films.

For example, «Ta Kung Pao» published a Shanghai audience's film review, his words told the heart of many Shanghainese: «In the great film of "The Liberated China", there are many shots that present Shanghai. Through these shots, we can see how Shanghai is formed into a city of malformed sin, and after liberation, how the Shanghai people celebrated getting a new life, and strive to defend the fruits of victory. As a Shanghai citizen, I can't help but feel the joy and pride when I look at these shots!» (Yu Shao, 1950, p. 6). Under the dual factors of excitement and market supply, how can the movie's attendance and screaming not rise?

Based on the box office results of the two documentary films in Shanghai film market, especially the gratifying social repercussions, in March 1951, Shanghai held an award ceremony for the 21 theaters that released «The Victory of the Chinese People». "The Central Bureau of Culture's Film has specially managed the award for the release of the work of «The Victory of the Chinese People», and was awarded by the Vice Mayor of the Shanghai Municipal People's Government. The winners are Da guang ming, Guo tai, and Mei qi. At the same time, the picket group of the theater staff also received the flag of the Central Film Bureau: «Consolidate the victory of the Chinese people's film» (Yu shao, 31 January 1951), and the theaters that released the film also jointly presented flags to the Central Film Bureau, which was accepted by the Deputy Director of the Cultural Bureau on behalf of the Film Bureau.

This is also the case in Changsha city, the ratio of the city's total audience to the city's total number of people is the highest in the country. Therefore, the Central Bureau of Culture's Film awards to the city's Silver 
Palace, Silver Star, Ping An, Workers' four cinemas (Yu shao, 31 January 1951). On the surface, this is to celebrate the increase in performance and achievements. In fact, due to the particularity of the film, the participants' actions have become public behaviors, rather than the awarding of the flag. Rather than presenting the flag as an expression of mutual gratitude, it was a gesture of affirmation and cooperation from the new regime led by the communist party of China to commercial cinemas, and also reflec the old private enterprise's approval of the new government.

\section{Conclusions}

In March 1951, «The Victory of the Chinese People» and «The Liberated China» both won the Stalin Prize of the Soviet Union. The leaders of the two countries attached great importance to providing sufficient quality resources and conditions for film production. These two documentaries represent the highest level of China's documentary film in the early days of the founding of the People's Republic of China. It is a friendship between China and the Soviet Union. In addition to the artistic value of the film itself, it also undertakes the documentary function of recording major events across the country.

For this two documentary films that carry the national memory, this paper returns to the video text and the historical time context. The national history and national conception in the film narrative are clear and accurate. Some narratives may seem dogmatic and well-worn today. However, in the early days of the founding of the People's Republic of China, it played an inspiring role in the formation of community-based psychology among the Shanghai residents, directly affecting the legitimacy of the regime and the basic construction of the country. For the promotion of «The Victory of the Chinese People» and «The Liberated China», the central coordinating force has hardly worked. Until today, few films can match those two. East China film Manager Company's flexible publicity strategy and extensive communication channels greatly promoted the film's performance effect. Then cultivated the Shanghai citizen's thought idea. The nationalist feeling of the Shanghai people and the new socialist regime was drawn up at an accelerated pace, which paved the way for the implementation of other policies.

Studying the identity of Shanghai people's approval to the will of the country, these two documentaries only opened an incision. There are still many individual cases and social phenomena in the film industry on the early days of the country foundation. Review and analysis of history will bring us more revelations, and provide an ideological source for a national image construction and the prospect of enhancing cultural soft power. 


\section{Contribution}

Yang Xi has been involved in this article preparation, data collect, drafting and final version approval.

\section{Funding}

Self funded.

\section{Disclaimer}

The author declares no conflict of interests. 


\section{REFERENCES}

Chen xi he (2015). Film ontology from the perspective of national theory. Art of Cinema, p. 22.

Duara, P. (2003). Why is history anti-theoretical? Huang zong zhi (Ed.), Discussion of paradigm in Chinese studies. Beijing: Social Science Literature Press.

Fang fang (2003). History of Chinese documentaries. Beijing: China drama Press.

Gao wei jin (2003). Chinese news documentary film history [M], Beijing: Central literature Press.

Jin Yan (September 29, 1950). Liberation Daily, p. 2.

(October 3, 1950). Liberation Daily, p. 2.

(November 3, 1950). Liberation Daily, p. 4.

(October 21, 1950). Statement by the representative of the theatrical film industry. Liberation Daily.

(December 30, 1950). The special column of «the liberated China». Liberation Daily.

Lin shao xiong, Chen jian feng (2009). Ideological image display: Documentary film development and the Cultural strategy of the ruling party. Shanghai: Shanghai people's Publishing House.

Shan wan li (2005). China records film history. Beijing: China Film Press.

Wu di (2006). Research materials on Chinese films from 1949 to 1979. Beijing: Beijing Culture and art Press.

Wu yi gong (1999). Shanghai film Chronicle. Shanghai: Shanghai Social Science Press.

Yang li ping (2006). On the sense of victory to Shanghai citizens in the early period of the new China. Journal of East China Normal University (philosophical and social science edition).

Yang yuan ying (2006). Research on the History of Chinese Professional Film. Beijing: China Film Press.

Yu shao (30 December 1950). Shanghai Images in «The liberated China» film. Ta Kung Pao, p. 6.

(31 January 1951). Cheers for the people's film, New film's Exhibition begins today. Wen Hui News, p. 1.

(31 January 1951). Workers' game. Wen Hui News, p. 1. 
Zhang shuo guo (2014). Culture research of Shanghai film in «The seventeen years». Beijing: Social Science Literature Press.

Recepción: 10/6/2018

Aceptación: 15/9/2018 